\title{
Optimal dose of hyperbaric bupivacaine $0.5 \%$ for unilateral spinal anesthesia during diagnostic knee arthroscopy
}

This article was published in the following Dove Press journal:

Local and Regional Anesthesia

25 August 2010

Number of times this article has been viewed

\section{HM Atef \\ AM El-Kasaby \\ MA Omera \\ MD Badr}

Department of Anesthesia and Intensive Care, Faculty of Medicine, Suez Canal University, Ismailia, Egypt

Correspondence: Hosam M Atef Department of Anesthesiology, Faculty of Medicine, Suez Canal University, Ismailia, Egypt

Email hosamatef375@yahoo.com
Objective: To determine the dose of hyperbaric bupivacaine $0.5 \%$ required for unilateral spinal anesthesia during diagnostic knee arthroscopy.

Patients and methods: This prospective, randomized, clinical study was performed in 80 patients who were assigned to four groups to receive different doses of intrathecal hyperbaric bupivacaine ( $5 \mathrm{mg}, 7.5 \mathrm{mg}, 10 \mathrm{mg}$ and $12.5 \mathrm{mg}$ in Groups 1, 2, 3, and 4 respectively). Onset of sensory and motor block, hemodynamic changes, regression of motor block, and incidence of complications were recorded.

Results: Unilateral sensory block was reported in $90 \%$ and $85 \%$ of patients in Group 1 and Group 2, respectively, but not in any patient in Group 3 and Group 4. Unilateral motor block (modified Bromage scale 0) was reported in 95\% of patients in Group 1,90\% in Group 2, and only 5\% in Group 3, while no patient in Group 4 showed unilateral motor block. The time required for regression of motor block (Bromage scale 0 ) was prolonged with higher doses. The incidence of nausea, vomiting, and urine retention was similar in the study groups.

Conclusion: Unilateral sensory and motor block can be achieved with doses of $5 \mathrm{mg}$ and $7.5 \mathrm{mg}$ hyperbaric bupivacaine $0.5 \%$ with a stable hemodynamic state. However, $7.5 \mathrm{mg}$ of hyperbaric bupivacaine $0.5 \%$ was the dose required for adequate unilateral spinal anesthesia.

Keywords: hyperbaric bupivacaine $0.5 \%$, unilateral spinal anesthesia, diagnostic knee arthroscopy

\section{Introduction}

Patients undergoing orthopedic surgery are of different ages and sizes. Regional analgesia and anesthesia are often beneficial for these patients. Knee arthroscopy is a common orthopedic procedure. This operation includes both diagnostic and operative procedures. The choices of anesthesia are as varied as the operations done through the scope, and include general blocks, central neuraxial blocks, peripheral nerve blocks, and intra-articular local anesthetic techniques. ${ }^{1}$ In the last decade, bupivacaine has been the most frequently used agent for spinal and epidural anesthesia. ${ }^{2,3}$ In ambulatory surgery, such as diagnostic knee arthroscopy, bupivacaine may delay the recovery of motor function and cause urinary retention, leading to delayed discharge. ${ }^{4,5}$

Unilateral spinal anesthesia is frequently used in lower limb surgery. ${ }^{6,7}$ Several advantages are claimed for this anesthetic technique, including fewer hemodynamic complications, ${ }^{8}$ selective block on the operated side, avoidance of unnecessary paralysis on the nonoperated side, better mobilization during the recovery period, lower incidence of postoperative urine retention, ${ }^{9}$ as well as good patient satisfaction. ${ }^{10}$ To achieve successful unilateral anesthesia, several factors are required, including needle 
shape and bevel direction, site and speed of injection of anesthetic, volume, baricity, and concentration of the anesthetic solution, as well as an appropriate degree of operating table inclination. ${ }^{11,12}$ Moreover, patient posture is thought to be fundamental in determining the level of anesthesia spread, particularly when a hyperbaric anesthetic solution is used. ${ }^{13}$

Previous studies have failed to determine the ideal dose of local anesthetic to achieve unilateral spinal anesthesia. Therefore, our aim was to evaluate the influence of the dose of hyperbaric bupivacaine on the success of unilateral spinal anesthesia by assessment of maximum sensory and motor block on the operative and nonoperative sides during knee arthroscopy and its effect on hemodynamics.

\section{Patients and methods}

This study was carried out as a prospective, randomized, double-blind clinical trial. After approval of the local ethics committee and informed patient consent was obtained, 80 male and female patients undergoing diagnostic knee arthroscopy in routine surgical theaters at the Suez Canal University Hospital in Ismailia were enrolled in this study. Inclusion criteria were American Society of Anesthesiologists (ASA) score I-II, age $21-50$ years, body mass index $<30 \mathrm{~kg} / \mathrm{m}^{2}$, and height 160-180 cm. Patients with skin infection at the site of regional anesthesia, coagulopathy, taking anticoagulant drugs, having allergy to local anesthetic drugs, hypovolemia, low fixed cardiac output, neurologic disorder, or spine deformity were excluded from the study. The patients were randomly allocated into four groups $(\mathrm{n}=20$ each) receiving different doses of hyperbaric bupivacaine $0.5 \%$. Group 1 received $5 \mathrm{mg}$, Group 2 received $7.5 \mathrm{mg}$, Group 3 received $10 \mathrm{mg}$, and Group 4 received $12.5 \mathrm{mg}$. All patients were given $2 \mathrm{mg}$ midazolam intravenously as premedication, as well as an intravenous infusion of $7 \mathrm{~mL} / \mathrm{kg}$ of lactated Ringer solution. Standard monitoring was used, including noninvasive blood pressure, electrocardiogram, peripheral pulse oximetry, and respiratory rate measurements.

\section{Procedure for spinal anesthesia}

All patients were placed in a lateral position on the operative side, while the vertebral column was positioned as horizontally as possible. Under complete aseptic technique and after back sterilization, dural puncture was performed using a midline approach at the L3-L4 interspace with a 25 gauge spinal needle. Using sealed envelopes prepared according to a computer generated randomization table, patients were randomly allocated to one of four groups. Patients in each group received different doses of bupivacaine (Marcaine Spinal Heavy, Astra,
Sweden), ie, Group 1 received $5 \mathrm{mg}$ bupivacaine $0.5 \% 1 \mathrm{~mL}$, Group 2 received $7.5 \mathrm{mg}$ bupivacaine $0.5 \% 1.5 \mathrm{~mL}$, Group 3 received $10 \mathrm{mg}$ bupivacaine $0.5 \% 2 \mathrm{~mL}$, and Group 4 received $12.5 \mathrm{mg}$ bupivacaine $0.5 \% 2.5 \mathrm{~mL}$. After observation of free flow of cerebrospinal fluid, the spinal needle aperture was turned toward the dependent side and the selected dose of local anesthetic solution was injected slowly with an injection speed of $0.5 \mathrm{~mL} / 10$ seconds without further aspiration maneuvers. Patients were maintained in the lateral decubitus position for a 20-minute period, after which patients were turned to the supine position. ${ }^{11,14}$

An independent blinded observer evaluated the evolution of sensory and motor blocks on both sides immediately after turning the patient supine for 20 minutes after the block, and then after 10 minutes. Sensory block was assessed as complete loss of sensation to pinprick (via a 23 gauge hypodermic needle). Motor block was assessed using a modified Bromage scale whereby patients were asked to flex the limb at the hip, knee, and ankle joints, and the results were recorded as $0=$ no motor block, 1 = hip blocked, 2 = hip and knee blocked, $3=$ hip, knee, and ankle blocked. ${ }^{9}$ Patients were judged ready for surgery when complete loss of pinprick sensation was reported at $\mathrm{T} 12$ on the operative limb.

Hemodynamic parameters were recorded. Postoperative analgesia included oral ketorolac (50 mg every eight hours), with the first dose administered before surgery by the intravenous route. ${ }^{9}$ Requirement for rescue analgesia was recorded. Intravenous tramadol $50 \mathrm{mg}$ was given. Motor and sensory block was monitored in the postanesthesia care unit at 10-minute intervals until time to complete regression of spinal block. Occurrence of adverse events, including nausea, vomiting, pruritus, and urine retention was also recorded.

Statistical analysis was performed using the program SPSS version 15 (SPSS Inc, Chicago, IL). Demographic data, onset times to anesthetic block, and surgery times were analyzed by one-way analysis of variance (ANOVA), whereas changes over time were analyzed with a two-way ANOVA for repeated measures. Categoric variables were analyzed using contingency table analysis and the Chi-square test with the appropriate corrections. Continuous variables were presented as means \pm standard deviations. Categoric data were presented as numbers and percentages. A $P$ value $<0.05$ was considered statistically significant.

\section{Results}

There were no significant differences in age, gender, body mass index, and duration of surgery between the patients in the four groups (Table 1). No statistically significant difference was 
Table I Personal characteristics of study population

\begin{tabular}{|c|c|c|c|c|c|}
\hline Characteristic & $\begin{array}{l}\text { Group I } \\
(n=20)\end{array}$ & $\begin{array}{l}\text { Group } 2 \\
(n=20)\end{array}$ & $\begin{array}{l}\text { Group } 3 \\
(n=20)\end{array}$ & $\begin{array}{l}\text { Group } 4 \\
(n=20)\end{array}$ & $P$ value \\
\hline Age (years, SD) & $36.1 \pm 11.5$ & $31.8 \pm 10.9$ & $39.1 \pm 12.4$ & $35.6 \pm 9.4$ & 0.2 \\
\hline Gender $(n, \%) M$ & $19(95)$ & $20(100)$ & $17(85)$ & $18(90)$ & 0.3 \\
\hline$F$ & I (5) & $0(0)$ & $3(15)$ & $2(10)$ & \\
\hline Height (m, SD) & $1.7 \pm 0.5$ & $1.7 \pm 0.9$ & $1.7 \pm 0.8$ & $1.7 \pm 0.6$ & 0.9 \\
\hline Body mass index (mean $\left.\mathrm{kg} / \mathrm{m}^{2}, \mathrm{SD}\right)$ & $24.3 \pm 2.6$ & $23.6 \pm 3.5$ & $25.1 \pm 1.4$ & $24.7 \pm 3.1$ & 0.4 \\
\hline Duration of surgery (min, SD) & $50.6 \pm 18.5$ & $54.4 \pm 17.9$ & $55.4 \pm 19.4$ & $54.5 \pm 18.1$ & 0.4 \\
\hline
\end{tabular}

Abbreviaton: SD, standard deviation.

found between the four groups for heart rate changes during surgery (Figure 1). There was a statistically significant decrease in mean arterial blood pressure in Group 3 and 4 patients who had been injected with $10 \mathrm{mg}$ and $12.5 \mathrm{mg}$, respectively. In Group 3, this drop lasted for only 15 minutes and, thereafter returned to near baseline values, while in Group 4 this drop remained until the end of the operation (Figure 2, Table 2).
Sensory block on the nonoperative side was significantly less than that on the operative side. In Group 1 and in Group 2, strict unilateral anesthesia was reported among $90 \%$ and $85 \%$ of patients, respectively, in whom the level of sensory block on the operative side was T10 and T8, respectively. In groups 3 and 4, none of the studied patients showed strict unilateral spinal anesthesia and the sensory block in the non-operative

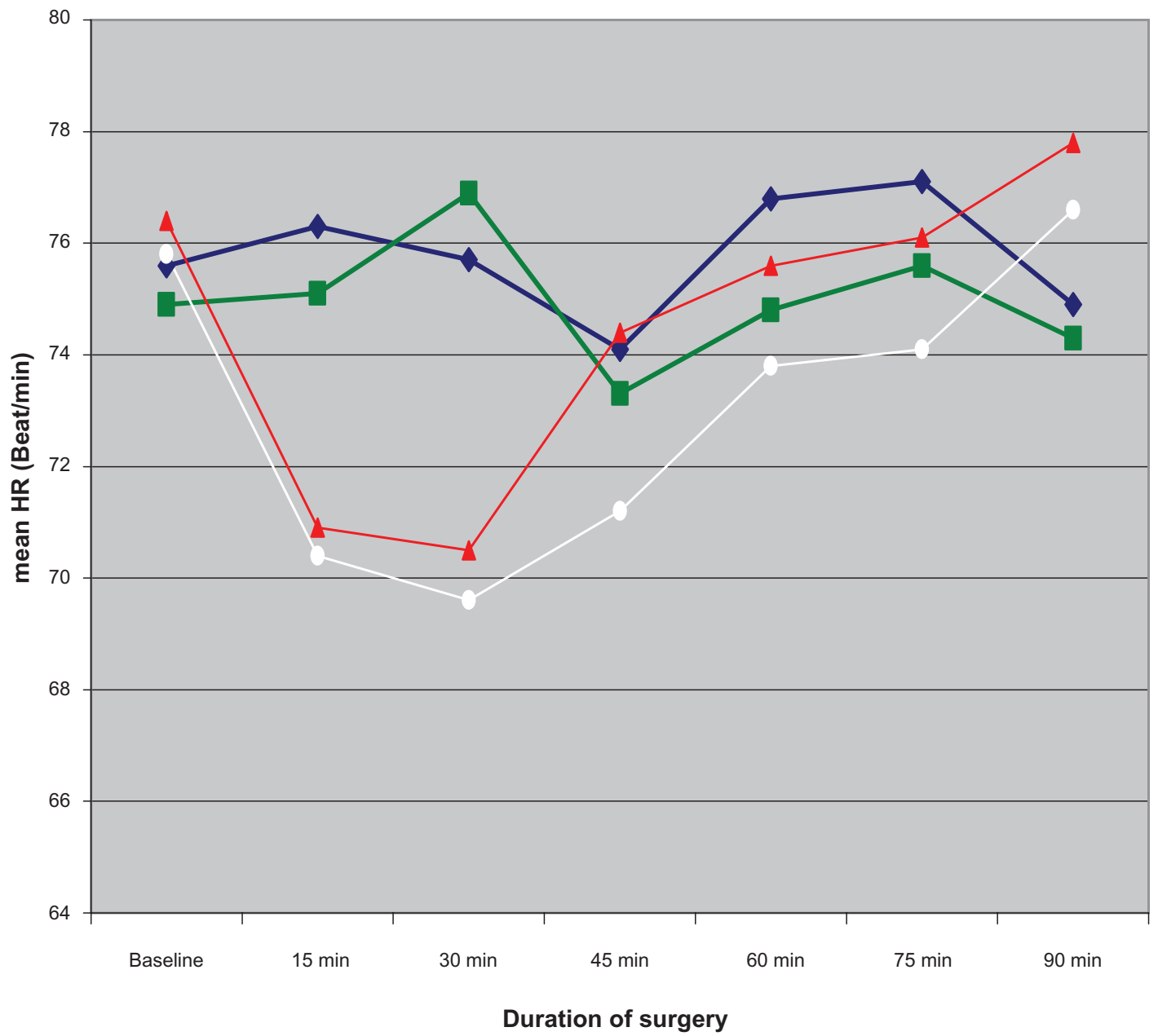

Group $1 \leftarrow$ Group $2 \leftarrow$ Group $3-$ Group 4

Figure I Heart rate changes throughout the operation among the studied patients in the 4 studied groups. 


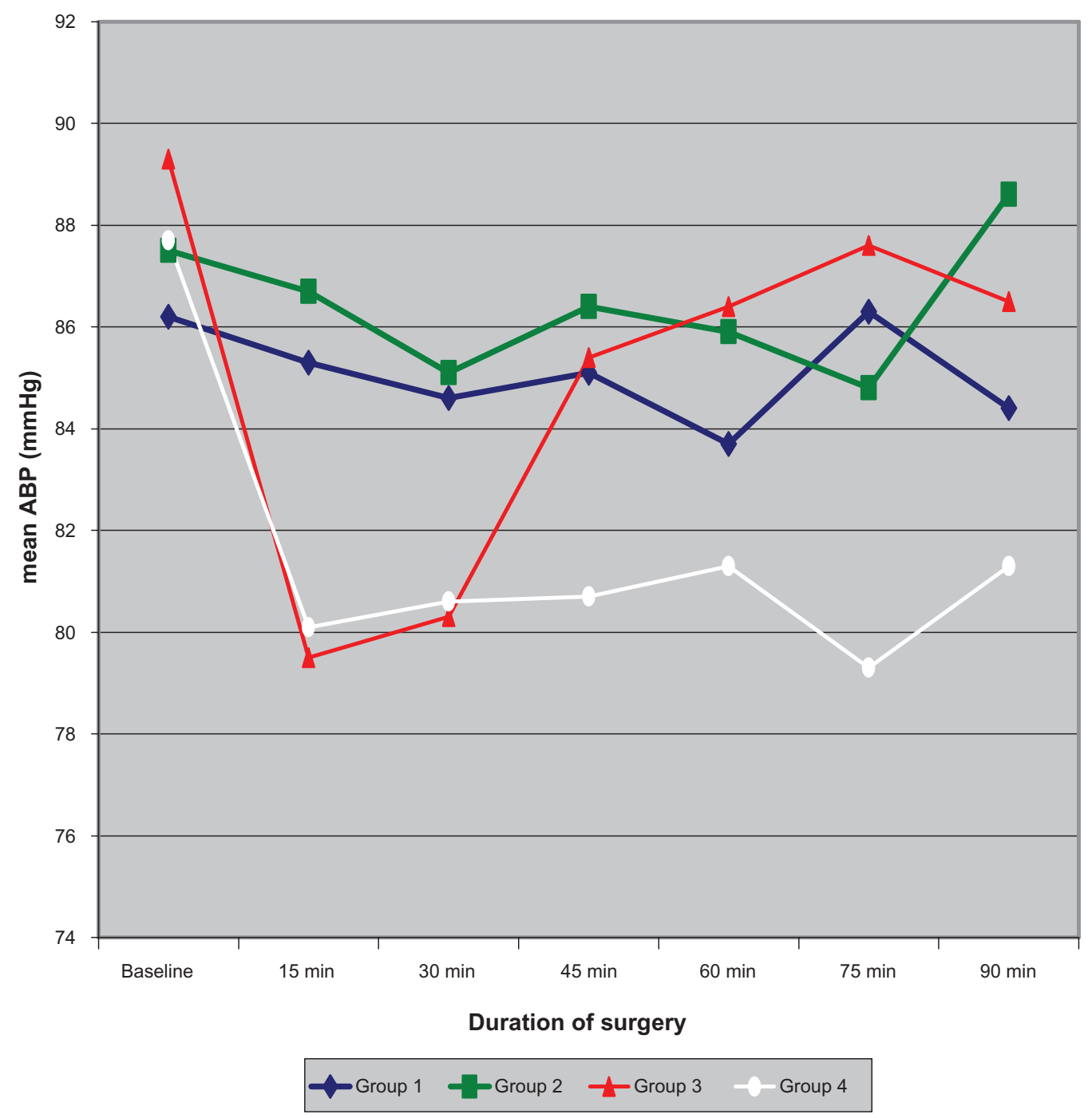

Figure 2 Mean arterial blood pressure changes $(\mathrm{mmHg})$ throughout the operation among the studied patients in the 4 studied groups.

side reached $\mathrm{T} 12$ and $\mathrm{T} 8$ levels, respectively, while the level of sensory block in the operative limb reached T6 and T5, respectively (Tables 3, 4, and 5).

Motor block on the operative side was statistically significant when compared with the nonoperative side $(P<0.05)$.
Motor block on the operative side in Groups 2, 3, and 4 was statistically significant compared with motor block on operative side in Group 1, while no statistically significant difference was reported when comparing pairs of the former three groups. Unilateral motor block (modified Bromage

Table 2 Mean arterial blood pressure changes

\begin{tabular}{|c|c|c|c|c|c|}
\hline \multirow[t]{2}{*}{$\begin{array}{l}\text { Mean arterial blood } \\
\text { pressure }(\mathrm{mmHg})\end{array}$} & $\begin{array}{l}\text { Group I } \\
(n=20)\end{array}$ & $\begin{array}{l}\text { Group } 2 \\
(n=20)\end{array}$ & $\begin{array}{l}\text { Group } 3 \\
(n=20)\end{array}$ & $\begin{array}{l}\text { Group } 4 \\
(n=20)\end{array}$ & \multirow[t]{2}{*}{$P$ value } \\
\hline & Mean \pm SD & Mean \pm SD & Mean \pm SD & Mean \pm SD & \\
\hline Baseline & $86.2 \pm 5.3$ & $87.5 \pm 4.7$ & $89.3 \pm 6.2$ & $87.7 \pm 3.4$ & 0.9 \\
\hline After 15 minutes & $85.3 \pm 4.2$ & $86.7 \pm 5.2$ & $79.5 \pm 5.8 * *$ & $80.1 \pm 5.2 * *$ & $0.00 *$ \\
\hline After 30 minutes & $84.6 \pm 6.1$ & $85.1 \pm 3.9$ & $80.3 \pm 6.3 * *$ & $80.6 \pm 4.6 * *$ & $0.00 I^{*}$ \\
\hline After 45 minutes & $85.1 \pm 5.8$ & $86.4 \pm 5.1$ & $85.4 \pm 4.9 * *$ & $80.7 \pm 5.5^{* *}$ & $0.001 *$ \\
\hline After 60 minutes & $83.7 \pm 4.9$ & $85.9 \pm 4.8$ & $86.4 \pm 5.2$ & $8 I .3 \pm 5 . I^{* *}$ & $0.001 *$ \\
\hline After 75 minutes & $86.3 \pm 5.2$ & $84.8 \pm 5.3$ & $87.6 \pm 5.7$ & $79.3 \pm 5.6 * *$ & $0.00 *$ \\
\hline After 90 minutes & $84.4 \pm 6.9$ & $88.6 \pm 4.9$ & $86.5 \pm 6.1$ & $81.3 \pm 5.9 * *$ & $0.002 *$ \\
\hline
\end{tabular}

Notes: *Statistically significant difference among all four groups ( $P$ value $<0.05)$; **Statistically significant difference versus baseline reading of the same group $(P$ value $<0.05)$. Abbreviation: SD, standard deviation. 
Table 3 Sensory block on operative and nonoperative side after 30 minutes of block

\begin{tabular}{|c|c|c|c|c|c|c|c|c|c|c|c|c|c|c|c|}
\hline & No level & L5 & L4 & L3 & L2 & LI & TI2 & TII & TIO & T9 & T8 & T7 & T6 & T5 & \\
\hline \multirow{4}{*}{$\begin{array}{l}\bar{o} \\
\text { ò } \\
\text { ò }\end{array}$} & $O p^{\ddagger \dagger}$ & 0 & 0 & 0 & 0 & 0 & 0 & 9 & 6 & 5 & 0 & 0 & 0 & 0 & 0 \\
\hline & & $0 \%$ & $0 \%$ & $0 \%$ & $0 \%$ & $0 \%$ & $0 \%$ & $45 \%$ & $30 \%$ & $25 \%$ & $0 \%$ & $0 \%$ & $0 \%$ & $0 \%$ & $0 \%$ \\
\hline & Nonop & 18 & 2 & 0 & 0 & 0 & 0 & 0 & 0 & 0 & 0 & 0 & 0 & 0 & 0 \\
\hline & & $90 \%$ & $10 \%$ & $0 \%$ & $0 \%$ & $0 \%$ & $0 \%$ & $0 \%$ & $0 \%$ & $0 \%$ & $0 \%$ & $0 \%$ & $0 \%$ & $0 \%$ & $0 \%$ \\
\hline & Op*t‡ & 0 & 0 & 0 & 0 & 0 & 0 & 3 & 5 & 6 & 4 & 2 & 0 & 0 & 0 \\
\hline \multirow{3}{*}{$\begin{array}{l}N \\
\text { ò } \\
\text { ở } \\
\text { vi }\end{array}$} & & $0 \%$ & $0 \%$ & $0 \%$ & $0 \%$ & $0 \%$ & $0 \%$ & $15 \%$ & $25 \%$ & $30 \%$ & $20 \%$ & $10 \%$ & $0 \%$ & $0 \%$ & $0 \%$ \\
\hline & Nonop & 17 & 2 & 1 & 0 & 0 & 0 & 0 & 0 & 0 & 0 & 0 & 0 & 0 & 0 \\
\hline & & $85 \%$ & $10 \%$ & $5 \%$ & $0 \%$ & $0 \%$ & $0 \%$ & $0 \%$ & $0 \%$ & $0 \%$ & $0 \%$ & $0 \%$ & $0 \%$ & $0 \%$ & $0 \%$ \\
\hline \multirow{5}{*}{$\begin{array}{l}\text { m } \\
\text { 号 } \\
\text { ò } \\
\text { Uे }\end{array}$} & $O p^{\dagger *}$ & 0 & 0 & 0 & 0 & 0 & 0 & 0 & 0 & 2 & 5 & 8 & 4 & I & 0 \\
\hline & & $0 \%$ & $0 \%$ & $0 \%$ & $0 \%$ & $0 \%$ & $0 \%$ & $0 \%$ & $0 \%$ & $10 \%$ & $25 \%$ & $40 \%$ & $20 \%$ & $5 \%$ & $0 \%$ \\
\hline & Nonop & 0 & 0 & 0 & 4 & 6 & 5 & 5 & 0 & 0 & 0 & 0 & 0 & 0 & 0 \\
\hline & & $0 \%$ & $0 \%$ & $0 \%$ & $20 \%$ & $30 \%$ & $25 \%$ & $25 \%$ & $0 \%$ & $0 \%$ & $0 \%$ & $0 \%$ & $0 \%$ & $0 \%$ & $0 \%$ \\
\hline & Op* & 0 & 0 & 0 & 0 & 0 & 0 & 0 & 0 & 0 & 0 & 2 & 5 & 6 & 7 \\
\hline \multirow{3}{*}{$\begin{array}{l}+ \\
\text { ò } \\
\text { ò } \\
\text { v }\end{array}$} & & $0 \%$ & $0 \%$ & $0 \%$ & $0 \%$ & $0 \%$ & $0 \%$ & $0 \%$ & $0 \%$ & $0 \%$ & $0 \%$ & $10 \%$ & $25 \%$ & $30 \%$ & $35 \%$ \\
\hline & Nonop & 0 & 0 & 0 & 0 & 0 & 0 & 7 & 6 & 4 & 2 & I & 0 & 0 & 0 \\
\hline & & $0 \%$ & $0 \%$ & $0 \%$ & $0 \%$ & $0 \%$ & $0 \%$ & $35 \%$ & $30 \%$ & $20 \%$ & $10 \%$ & $5 \%$ & $0 \%$ & $0 \%$ & $0 \%$ \\
\hline
\end{tabular}

Notes: *Statistically significant difference between operative and nonoperative side in each group $(P<0.05)$; ${ }^{\dagger}$ Statistically significant difference versus operative side in Group 4 ( $P$ value $<0.05$ ); \$Statistically significant difference versus operative side in Group $3(P<0.05)$.

Abbreviations: op, operative side; nonop, nonoperative side.

scale 0 ) was reported in $95 \%$ of patients in Group 1, 90\% in Group 2, and only 5\% in Group 3, while none of the patients in Group 4 showed unilateral motor block (Table 6).

The time required for regression of motor block (Bromage scale 0 ) was more prolonged with higher doses and the difference was statistically significant. The regression time was 59.8 (55-100), 98.3 (60-120),123.9 (60-150), and 148.9 (110-180) minutes for Groups 1, 2, 3, and 4 respectively. The incidence of nausea, vomiting, and urine retention was similar in the four study groups (Table 7).

\section{Discussion}

The ideal selective spinal anesthesia for knee arthroscopy would provide minimal or no motor blockade at the end of the surgical procedure, such that the patient can be fast tracked. ${ }^{5}$ Using a minidose of lidocaine-fentanyl ${ }^{15}$ or hyperbaric bupivacaine, ${ }^{16}$ Ben-David et al discharged their knee arthroscopy patients at 145 minutes and 202 minutes, respectively.

As regards the hemodynamic effects of different doses of hyperbaric bupivacaine during surgery, no statistically significant differences were found between the four study groups

Table 4 Significance of the difference ( $P$ value) between sensory block on different operative sides

\begin{tabular}{lllll}
\hline & Group I & Group 2 & Group 3 & Group 4 \\
\hline Group I & & & & \\
Group 2 & 0.06 & & & \\
Group 3 & $0.000 I^{*}$ & $0.004^{*}$ & & \\
Group 4 & $0.000 I^{*}$ & $0.000 I^{*}$ & $0.0007^{*}$ & \\
\hline
\end{tabular}

*Statistically significant difference. with regard to heart rate changes during surgery. Hemodynamic benefits have also increased interest in unilateral spinal anesthesia. Hypotension is a common complication of spinal anesthesia, occurring in $15 \%{ }^{17}$ to $33 \%{ }^{18}$ of patients when larger doses of local anesthetic have been used. Unilateral spinal anesthesia with hypobaric or hyperbaric bupivacaine was associated with less hypotension, ${ }^{19,20}$ which is consistent with our results.

In our study, unilateral spinal anesthesia (regarding sensory block) was reported by $90 \%$ and $85 \%$ of patients in Group 1 and Group 2, respectively, while in Group 3 and Group 4 none of the studied patients showed unilateral anesthesia. For motor block, unilateral anesthesia was recorded in $95 \%$ of patients in Group 1,90\% in Group 2, and only 5\% in Group 3, while none of the patients in Group 4 showed unilateral spinal anesthesia.

Valanne et $\mathrm{al}^{21}$ compared the effect of $4 \mathrm{mg}$ and $6 \mathrm{mg}$ of hyperbaric bupivacaine for spinal anesthesia in 106 ambulatory adult patients undergoing knee arthroscopy. They found that both doses produced efficient and adequate sensory and motor block. However, rapid regaining of motor function was reported with the lower dose.

Table 5 Significance of the difference ( $P$ value) of sensory block on nonoperative side

\begin{tabular}{lllll}
\hline & Group I & Group 2 & Group 3 & Group 4 \\
\hline Group I & & & \\
Group 2 & 0.8 & & \\
Group 3 & $0.000 I^{*}$ & $0.000 I^{*}$ & & \\
Group 4 & $0.000 I^{*}$ & $0.000 I^{*}$ & $0.0002 *$ & \\
\hline
\end{tabular}

*Statistically significant difference. 
Table 6 Motor block in operative and nonoperative side after 30 minutes of block

\begin{tabular}{llllll}
\hline & & $\begin{array}{l}\text { No } \\
\text { motor } \\
\text { block }\end{array}$ & $\begin{array}{l}\text { Hip } \\
\text { blocked }\end{array}$ & $\begin{array}{l}\text { Hip and } \\
\text { knee } \\
\text { blocked }\end{array}$ & $\begin{array}{l}\text { Hip, } \\
\text { knee } \\
\text { and ankle } \\
\text { blocked }\end{array}$ \\
\hline Group I & Operative* & $0(0 \%)$ & $0(0 \%)$ & $10(50 \%)$ & $10(50 \%)$ \\
& Nonoperative & $19(95 \%)$ & $1(5 \%)$ & $0(0 \%)$ & $0(0 \%)$ \\
Group 2 & Operative*t & $0(0 \%)$ & $0(0 \%)$ & $2(10 \%)$ & $18(90 \%)$ \\
& Nonoperative & $18(90 \%)$ & $2(10 \%)$ & $0(0 \%)$ & $0(0 \%)$ \\
Group 3 & Operative*t & $0(0 \%)$ & $0(0 \%)$ & $2(10 \%)$ & $18(90 \%)$ \\
& Nonoperative & $1(5 \%)$ & $7(35 \%)$ & $9(45 \%)$ & $3(15 \%)$ \\
Group 4 & Operative ${ }^{\dagger}$ & $0(0 \%)$ & $0(0 \%)$ & $1(5 \%)$ & $19(95 \%)$ \\
& Nonoperative & $0(0 \%)$ & $0(0 \%)$ & $5(25 \%)$ & $15(75 \%)$ \\
\hline
\end{tabular}

Notes: *Statistically significant difference between operative and nonoperative side in each group $(P<0.05)$; †Statistically significant difference versus operative side in Group I ( $P$ value $<0.05)$.

In our study, the time to regression of motor block was found to be significantly increased with increasing the injected dose of hyperbaric bupivacaine, with mean times of 59.8, 98.3, 123.6 and 148.9 minutes in Groups 1, 2, 3, and 4 , respectively.

In another study, Fanelli et $\mathrm{al}^{9}$ compared unilateral and conventional bilateral bupivacaine spinal block in outpatients undergoing knee arthroscopy. In the unilateral group, they used $8 \mathrm{mg}$ of hyperbaric bupivacaine $0.5 \%$ in 50 patients in lateral decubitus position after spinal injection was maintained in the unilateral group for 15 minutes. They found that, for the unilateral group, sensory and motor blocks on the operated limb were T9 (T12-T2) with a Bromage score 0/1/2/3 in $0 / 2 / 3 / 45$ patients, respectively, in the unilateral group. Two segment regressions of sensory level and home discharge required $81 \pm 25$ minutes and $281 \pm 83$ minutes with bilateral block, and $99 \pm 28$ minutes and $264 \pm 95$ minutes with unilateral block.

Borghi et $\mathrm{al}^{22}$ carried out a prospective, randomized, blinded study among 90 ASA I and II outpatients scheduled for elective knee arthroscopy. After placement of the patients in the lateral decubitus position, they received spinal block with 4,6 , or $8 \mathrm{mg}$ of $0.5 \%$ hyperbaric bupivacaine on the operative side, injected slowly with the needle orifice directed toward the dependent side using a 25-gauge Whitacre needle. The lateral decubitus position was maintained for 15 minutes. The maximum level of sensory block on the operative and nonoperative sides was, respectively, T10 (T12-T6) and ( $<\mathrm{L} 2)$ in the $4 \mathrm{mg}$ group, T8 (T12-T6) and $(<\mathrm{L} 5)$ in the $6 \mathrm{mg}$ group, and T7 (T12-T5) and $(<\mathrm{T} 10)$ in the $8 \mathrm{mg}$ group. Unilateral sensory block was observed in 27 patients in the $4 \mathrm{mg}$ group (90\%), 28 patients in the $6 \mathrm{mg}$ group (93\%), and 23 patients in the $8 \mathrm{mg}$ group (77\%, $P<0.28)$. Complete unilateral motor block was observed in 29 patients in the $4 \mathrm{mg}$ group (97\%), 28 patients in the $6 \mathrm{mg}$ group (93\%), and 28 patients in the $8 \mathrm{mg}$ group (93\%, $P=0.80)$. No failed blocks were reported. Complete regression of spinal anesthesia required $71 \pm 20$ minutes in the $4 \mathrm{mg}$ group (range 40-110 minutes), $82 \pm 25$ minutes in the $6 \mathrm{mg}$ group (range 30-160 minutes), and $97 \pm 37$ minutes in the $8 \mathrm{mg}$ group (range 50 to 120 minutes).

Analysis of side effects showed that the injected dose did not affect the incidence of side effects, such as nausea, vomiting, urinary retention, or need for analgesia.

Although our study was different from other studies regarding dose, position, and patients being kept on the lateral side for 20 minutes, our results were found to be consistent with earlier ones because higher doses of hyperbaric bupivacaine were associated with higher levels of maximum sensory and motor block and longer duration to achieve regression of sensory block.

\section{Conclusion}

Unilateral sensory and motor block, a faster recovery profile, and a stable hemodynamic state can be achieved with doses of $5 \mathrm{mg}$ and $7.5 \mathrm{mg}$ of hyperbaric bupivacaine $0.5 \%$ injected slowly through pencil-point directional needles in patients who are maintained in the lateral decubitus position for 20 minutes. However, $7.5 \mathrm{mg}$ of hyperbaric bupivacaine $0.5 \%$ was the dose required for adequate unilateral spinal anesthesia with adequate sensory and motor block.

Table 7 Time to regression of motor block (Bromage scale 0), incidence of complications, and rescue analgesia requirements

\begin{tabular}{|c|c|c|c|c|c|}
\hline Characteristic & $\begin{array}{l}\text { Group I } \\
(n=20)\end{array}$ & $\begin{array}{l}\text { Group } 2 \\
(n=20)\end{array}$ & $\begin{array}{l}\text { Group } 3 \\
(n=20)\end{array}$ & $\begin{array}{l}\text { Group } 4 \\
(n=20)\end{array}$ & $P$ value \\
\hline Time for regression of block (minutes) & $59.8 \pm 14.6$ & $98.3 \pm 15.8$ & $123.6 \pm 9.7$ & $148.9 \pm 10.3$ & $0.001 *$ \\
\hline Nausea/vomiting & $0(0 \%)$ & $\mathrm{I}(5 \%)$ & $0(0 \%)$ & $2(10 \%)$ & 0.3 \\
\hline Urinary retention & $0(0 \%)$ & $0(0 \%)$ & I (5\%) & I (5\%) & 0.6 \\
\hline $\begin{array}{l}\text { Number of patients needing } \\
\text { rescue analgesia }\end{array}$ & $3(15 \%)$ & I (5\%) & $0(0 \%)$ & $0(0 \%)$ & 0.09 \\
\hline
\end{tabular}

*Statistically significant difference. 


\section{Disclosure}

The authors report no conflict of interest in this work.

\section{References}

1. White PF. Outpatient anesthesia. In: Miller RD, editor. Anesthesia. 3rd ed. New York, NY: Churchill-Livingstone; 1990.

2. Eberhart LH, Morin AM, Kranke P, Geldner G, Wulf H. Transient neurologic symptoms after spinal anesthesia. A quantitative systematic overview (meta-analysis) of randomized controlled studies. Anaesthesist. 2002;51:539-546. German.

3. Pollock JE. Neurotoxicity of intrathecal local anaesthetics and transient neurological symptoms. Best Pract Res Clin Anaesthesiol. 2003;17: 471-484.

4. Korhonen AM, Valanne J, Jokela R, Ravaska P, Korttila K. Intrathecal hyperbaric bupivacaine $3 \mathrm{mg}+$ fentanyl $10 \mu \mathrm{g}$ for outpatient knee arthroscopy with tourniquet. Acta Anaesthesiol Scand. 2003;47: 342-346.

5. Vaghadia H, Viskari D, Mitchell GW, Berrill A. Selective spinal anesthesia for outpatient laparoscopy. I: Characteristics of three hypobaric solutions. Can J Anaesth. 2001;48:256-260.

6. Esmaoglu A, Karaoglu S, Mizrak A, Boyaci A. Bilateral vs unilateral spinal anaesthesia for outpatient knee arthroscopies. Knee Surg Sports Traumatol Arthrosc. 2003;12:155-158.

7. Sotig D, Greilich NB, White PF, Watcha MF, Tongier WK. Recovery profiles and costs of anesthesia for outpatient unilateral inguinal herniorrhaphy. Anesth Analg. 2000;91:876-881.

8. Casati A, Fanelli G, Aldegheri G, et al. Frequency of hypotension during conventional or asymmetric hyperbaric spinal block. Reg Anesth Pain Med. 1999;24:214-219.

9. Fanelli G, Borghi B, Casati A, Bertini L, Montebugnoli M, Torri G. Unilateral bupivacaine spinal anesthesia for outpatient knee arthroscopy. Italian Study Group on Unilateral Spinal Anesthesia. Can J Anaesth. 2000;47:746-751.

10. Liu SS, Ware PD, Allen HW, Neal JM, Pollock JE. Dose response characteristics of spinal bupivacaine in volunteers. Clinical implications for ambulatory anesthesia. Anesthesiology. 1996;85:729-736.
11. Casati A, Fanelli G. Unilateral spinal anesthesia. State of the art Minerva Anestesiol. 2001;67:855-862.

12. Kuusniemi KS, Pihlajamaki KK, Pitkanen MT. A low dose of plain or hyperbaric bupivacaine for unilateral spinal anesthesia. Reg Anesth Pain Med. 2000;25:605-610.

13. Al Malyan M, Becchi C, Falsini S, et al. Role of patient posture during puncture on successful unilateral spinal anaesthesia in outpatient lower abdominal surgery. Eur J Anaesthesiol. 2006;23:6:491-495.

14. Cindea I, Balcan A, Gherghina V, Nicolae G. Unilateral spinal anesthesia versus conventional spinal anesthesia in ambulatory lower abdominal surgery. Eur J Anaesthesiol. 2007;24:10.

15. Ben-David B, Maryanovsky M, Gurevitch A, et al. A comparison of minidose lidocaine-fentanyl and conventional dose lidocaine spinal anesthesia. Anesth Analg. 2000;91:865-870.

16. Ben-David B, DeMeo PJ, Lucyk C, Solosko D. A comparison of minidose lidocaine-fentanyl spinal anesthesia and local anesthesia/propofol infusion for outpatient knee arthroscopy. Anesth Analg. 2001;93: 319-325.

17. Tarkkila P, Isola J. A regression model for identifying patients at high risk of hypotension, bradycardia and nausea during spinal anesthesia. Acta Anaesthesiol Scand. 1992;36:554-558.

18. Carpenter RL, Caplan RA, Brown DL, Stephenson C, Wu R. Incidence and risk factors for side effects of spinal anesthesia. Anesthesiology. 1992;76:906-916.

19. Casati A, Fanelli G, Cappelleri G, et al. Does speed of intrathecal injection affect the distribution of $0.5 \%$ hyperbaric bupivacaine? Br J Anaesth. 1998;81:355-357.

20. Karpel E, Marszołek P, Pawlak B, Wach E. Effectiveness and safety of unilateral spinal anaesthesia. Anestezjol Intens Ter. 2009;41:33-36. Swedish.

21. Valanne JV, Korhonen A, Jokela RM, Ravaska P, Korttila KK. Selective spinal anesthesia: A comparison of hyperbaric bupivacaine $4 \mathrm{mg}$ versus $6 \mathrm{mg}$ for outpatient knee arthroscopy. Anesth Analg. 2001;93: 1377-1379.

22. Borghi B, Stagni F, Bugamelli S, et al. Unilateral spinal block for outpatient knee arthroscopy: A dose-finding study. J Clin Anesth. 2003;15: $351-356$.
Local and Regional Anesthesia

\section{Publish your work in this journal}

Local and Regional Anesthesia is an international, peer-reviewed, open access journal publishing on the development, pharmacology, delivery and targeting and clinical use of local and regional anesthetics and analgesics. The journal welcomes submitted papers covering original research, basic science, clinical studies, reviews \& evaluations,

\section{Dovepress}

guidelines, expert opinion and commentary, case reports and extended reports. The manuscript management system is completely online and includes a very quick and fair peer-review system, which is all easy to use. Visit http://www.dovepress.com/testimonials.php to read real quotes from published authors. 